\title{
Irvingia gabonensis Seed Extract: An Effective Attenuator of Doxorubicin-Mediated Cardiotoxicity in Wistar Rats
}

\author{
Olufunke Olorundare, ${ }^{1}$ Adejuwon Adeneye $\mathbb{D}^{2},{ }^{2}$ Akinyele Akinsola, ${ }^{1}$ Phillip Kolo, ${ }^{3}$ \\ Olalekan Agede, ${ }^{1}$ Sunday Soyemi, ${ }^{4}$ Alban Mgbehoma, ${ }^{5}$ Ikechukwu Okoye, ${ }^{6}$ Ralph Albrecht, ${ }^{7}$ \\ and Hasan Mukhtar (iD) \\ ${ }^{1}$ Department of Pharmacology and Therapeutics, Faculty of Basic Medical Sciences, College of Health Sciences, University of Ilorin, \\ Ilorin, Kwara State, Nigeria \\ ${ }^{2}$ Department of Pharmacology, Therapeutics and Toxicology, Faculty of Basic Clinical Sciences, Lagos State University College \\ of Medicine, 1-5 Oba Akinjobi Way, G.R.A., Ikeja, Lagos State, Nigeria \\ ${ }^{3}$ Department of Medicine, Faculty of Clinical, College of Health Sciences, University of Ilorin, Ilorin, Kwara State, Nigeria \\ ${ }^{4}$ Department of Pathology and Forensic Medicine, Faculty of Basic Clinical Sciences, Lagos State University College of Medicine, 1 - \\ 5 Oba Akinjobi Way, G.R.A., Ikeja, Lagos State, Nigeria \\ ${ }^{5}$ Department of Pathology and Forensic Medicine, Lagos State University Teaching Hospital, 1-5 Oba Akinjobi Way, G.R.A., Ikeja, \\ Lagos State, Nigeria \\ ${ }^{6}$ Department of Oral Pathology and Medicine, Faculty of Dentistry, Lagos State University College of Medicine, 1-5 Oba \\ Akinjobi Way, G.R.A., Ikeja, Lagos State, Nigeria \\ ${ }^{7}$ Department of Animal Sciences, 1675 Observatory Drive, University of Wisconsin, Madison, WI 53706, USA \\ ${ }^{8}$ Department of Dermatology, University of Wisconsin, Madison, Medical Science Center, 1300 University Avenue, Madison, \\ WI 53706, USA
}

Correspondence should be addressed to Adejuwon Adeneye; adeneye2001@yahoo.com

Received 31 July 2020; Revised 8 September 2020; Accepted 5 October 2020; Published 23 October 2020

Academic Editor: Patricia Morales

Copyright ( $) 2020$ Olufunke Olorundare et al. This is an open access article distributed under the Creative Commons Attribution License, which permits unrestricted use, distribution, and reproduction in any medium, provided the original work is properly cited.

Cardiotoxicity as an off-target effect of doxorubicin therapy is a major limiting factor for its clinical use as a choice cytotoxic agent. Seeds of Irvingia gabonensis have been reported to possess both nutritional and medicinal values which include antidiabetic, weight losing, antihyperlipidemic, and antioxidative effects. Protective effects of Irvingia gabonensis ethanol seed extract (IGESE) was investigated in doxorubicin (DOX)-mediated cardiotoxicity induced with single intraperitoneal injection of $15 \mathrm{mg} / \mathrm{kg}$ of DOX following the oral pretreatments of Wistar rats with $100-400 \mathrm{mg} / \mathrm{kg} / \mathrm{day}$ of IGESE for 10 days, using serum cardiac enzyme markers (cardiac troponin I (cTI) and lactate dehydrogenase (LDH)), cardiac tissue oxidative stress markers (catalase (CAT), malonyldialdehyde (MDA), superoxide dismutase (SOD), glutathione-S-transferase (GST), glutathione peroxidase (GSH-Px), and reduced glutathione (GSH)), and cardiac histopathology endpoints. In addition, both qualitative and quantitative analyses to determine IGESE's secondary metabolites profile and its in vitro antioxidant activities were also conducted. Results revealed that serum cTnI and LDH were significantly elevated by the DOX treatment. Similarly, activities of tissue SOD, CAT, GST, and GSH levels were profoundly reduced, while GPx activity and MDA levels were profoundly increased by DOX treatment. These biochemical changes were associated with microthrombi formation in the DOX-treated cardiac tissues on histological examination. However, oral pretreatments with $100-400 \mathrm{mg} / \mathrm{kg}$ /day of IGESE dissolved in 5\% DMSO in distilled water significantly attenuated increases in the serum $\mathrm{CTnI}$ and $\mathrm{LDH}$, prevented significant alterations in the serum lipid profile and the tissue activities and levels of oxidative stress markers while improving cardiovascular disease risk indices and DOX-induced histopathological lesions. The in vitro antioxidant studies showed IGESE to have good antioxidant profile and contained 56 major secondary metabolites prominent among which are $\gamma$-sitosterol, Phytol, neophytadiene, stigmasterol, vitamin E, hexadecanoic acid and its ethyl ester, Phytyl palmitate, campesterol, lupeol, and squalene. Overall, both the in vitro and in vivo findings indicate that IGESE may be a promising prophylactic cardioprotective agent against DOX-induced cardiotoxicity, at least in part mediated via IGESE's antioxidant and free radical scavenging and antithrombotic mechanisms. 


\section{Introduction}

Doxorubicin (otherwise known as Adriamycin) is one of the antibiotic cytotoxic agent belonging to the anthracycline class of anticancer agents [1]. Doxorubicin is known to bind to and intercalate with DNA, thereby inhibiting the resealing action of topoisomerase II during normal DNA replication needed for cancer cell division and growth [2-5]. Doxorubicin is often used in clinical setting in combination with other classes of anticancer agents as "chemo cocktail" in the management of various types of solid and blood cancers such as breast and ovarian, leukemia (acute myelogenous leukemia (AML) and acute lymphoblastic leukemia), Hodgkin lymphoma, non-Hodgkin lymphoma, Wilm's tumor, neuroblastoma, and sarcoma [6-8]. For example, for breast cancer management, doxorubicin is typically combined and given with cyclophosphamide; for lymphomas and leukemias, it is combined with other cytotoxic agents to make regimens like CHOP (cyclophosphamide, doxorubicin hydrochloride, vincristine sulfate, and prednisone), R-CHOP (rituximab, cyclophosphamide, doxorubicin hydrochloride, vincristine sulfate, and prednisone), and ABVD (doxorubicin, bleomycin, vinblastine, dacarbazine) [9-12]. However, the clinical use of doxorubicin have been reported to be associated with major common side effects such as pain at the injection site, anorexia, fever, nausea and vomiting, stomatitis, dyspnea, nose bleeding, alopecia, immunosuppression, weight gain, hepatic and renal injuries, and severe cardiotoxicity $[3,13]$, while its occasional side effects include hyperuricemia, heart failure, pericardial effusion, cardiomyopathy, conjunctivitis, and skin rashes $[14,15]$. Of these side effects, cumulative and dose-related cardiomyopathy and heart failure are of grave concerns to cancer patients and managing physicians alike, thus, limiting its clinical use [16-18]. Although the pathogenesis of doxorubicin-induced cardiotoxicity has been reported to be complex and fuzzy, the pivotal role of ironmediated formation of reactive oxygen species (ROS) cannot be underscored [19].

In preventing the development of doxorubicin-induced cardiotoxicity, chemocurative and chemopreventive strategies involving the use of flavonoids, especially monoHER, have been advocated [20, 21]. MonoHER has been reported to elicit potent antioxidant, iron chelating, and carbonyl reductase inhibiting effects while still protecting the antitumor activity of anthracycline anticancer agents [22]. Similarly, the effectiveness of dexrazoxane (an iron chelating agent) $[5,23]$, dextromethionine $[24,25]$, and angiotensinconverting enzyme inhibitors-zofenopril and lisinopril $[26,27]$-in ameliorating doxorubicin-related cardiotoxicity have also been reported. These agents, especially dexrazoxane, are known to mitigate oxidative stress by chelating iron and catalytically inhibiting topoisomerase II, thus preventing doxorubicin-induced double strand DNA breaks [28, 29]. However, these chemopreventive agents are expensive and not readily accessible to patients, therefore, necessitating the need for the discovery and development of more effective but cheaper and more readily accessible alternatives especially ones of medicinal plant origin. One of these is the Irvingia gabonensis seed extract.
Irvingia gabonensis (Aubry-Le Comte ex O’Rorke) Bail belonging to the family, Irvingiaceae, is known as African Mango (in English). Its other common names include bread tree, African wild mango, wild mango, and bush mango [30, 31], and its local names include Apon (in Yoruba, Southwest Nigeria), Ogbono (in Igbo, Southeast Nigeria), and Goron or biri (in Hausa, Northern Nigeria) [32, 33]. Irvingia gabonensis is widely cultivated in West African countries including southwest and southeast Nigeria, southern Cameroon, Côte d'Ivoire, Ghana, Togo, and Benin, to produce its edible fruit whose seed is used in the preparation of local delicious viscous soup for swallowing yam and cassava puddings [34]. Fat extracted from its seeds is commonly known as dika fat and majorly consists of $\mathrm{C} 12$ and $\mathrm{C} 14$ fatty acids, alongside with smaller quantities of $\mathrm{C} 10, \mathrm{C} 16$, and $\mathrm{C} 18$, glycerides and proteins [34]. Irvingia gabonensis seeds are also a good source of nutrients including a variety of vitamins and minerals such as sodium, calcium, magnesium, phosphorus, and iron. It is also a rich source of flavonoids (quercetin and kaempferol), ellagic acid, mono-, di-, and tri-O-methylellagic acids, and their glycosides which are potent antioxidants $[35,36]$.

Phytochemical analysis of its seeds showed that it contains tannins, alkaloids, flavonoids, cardiac glycosides, steroids, carbohydrate, volatile oils, and terpenoids [33, 37, 38 ] and its proximate composition of moisture $1.4 \pm 0.11 \%$, ash $6.8 \pm 0.12 \%$, crude lipid $7.9 \pm 0.01 \%$, crude fiber $21.6 \pm$ $0.45 \%$, and crude protein $5.6 \pm 0.20 \%$ [33]. Pure compounds already isolated from the seed extract of include: methyl 2-[2formyl-5-(hydroxymethyl)-1 H-pyrrollyl]-propanoate, kaempferol-3-0- $\beta$-D-6" (p-coumaroyl) glucopyranoside and lupeol (3 $\beta$-lup-20(29)-en-3-ol). Erstwhile, the antioxidant property of Irvingia gabonensis seed extract has been largely attributed to its high lupeol content [39].

In view of the above, the current study was designed at evaluating the possible protective effect of the crude nondefatted ethanol seed extract of Irvingia gabonensis against doxorubicin-mediated cardiotoxicity in rats using cardiac injury markers, oxidative stress markers, and histopathology results as endpoint outcomes.

\section{Materials and Methods}

2.1. Extraction Process and Calculation of Percentage Yield. For Irvingia gabonensis seed extraction, $3 \mathrm{~kg}$ of pulverized Irvingia gabonensis dried seeds was macerated in $12 \mathrm{~L}$ of absolute ethanol for 72 hours after which it was continuously stirred for 1 hour before it was filtered using $180 \mathrm{~mm}$ of filter paper. The filtrate was then concentrated at $40^{\circ} \mathrm{C}$ to complete dryness using rotary evaporator. The dark-colored, oily paste-like residue left behind was weighed, stored in airand water-proof container which was kept in a refrigerator at $4^{\circ} \mathrm{C}$. This extraction process was repeated for two more times. From the stock, fresh solutions were made whenever required.

$\%$ yield was calculated as \{weight of crude extract obtained $(\mathrm{g}) \div$ weight of pulverized dry seed extracted $(\mathrm{g})\} \times$ 100 . 
2.2. Preliminary Qualitative Phytochemical Analysis of IGESE. The presence of saponins, tannins, alkaloids, flavonoids, anthraquinones, glycosides, and reducing sugars in IGESE was detected by the simple and standard qualitative methods described by Trease and Evans [40] and Sofowora [41].

2.3. Preliminary Quantitative Determination of Secondary Metabolites in and Phytoscan of IGESE. Preliminary quantitative analysis of the secondary metabolites (including phenol, flavonoids, tannin, terpenoids, steroids, reducing sugars, saponin, and phlobatannin) in IGESE was done using methods earlier described by Olorundare et al. [42]. Similarly, using gas chromatography-mass spectrophotometer (GC-MS) for phytoscan, the relative abundance of the secondary metabolites in IGESE was done using the procedures earlier described by Olorundare et al. [42].

2.4. In Vitro Antioxidant Studies of IGESE. DPPH scavenging activity, FRAP, and nitric oxide scavenging activities of IGESE were determined using the procedures earlier described by Olorundare et al. [42].

2.5. Experimental Animals. Young adult male Wistar Albino rats (aged 8-10 weeks old and body weight: 140-160 g) used in this study were obtained from the Animal House of the Lagos State University College of Medicine, Ikeja, Lagos State, Nigeria, after an ethical approval (UERC Approval number: UERC/ASN/2020/2022) was obtained from the University of Ilorin Ethical Review Committee for Postgraduate Research. The rats were handled in accordance with international principles guiding the Use and Handling of Experimental Animals [43]. The rats were maintained on standard rat feed (Ladokun Feeds, Ibadan, Oyo State, Nigeria) and potable water which were made available ad libitum. The rats were maintained at an ambient temperature between 28 and $30^{\circ} \mathrm{C}$, humidity of $55 \pm 5 \%$, and standard (natural) photoperiod of approximately $12 / 12$ hours of alternating light and dark periodicity.

2.6. Measurement of Body Weight. The rat body weights were taken at the beginning and last of the experiment using a digital rodent weighing scale ( ${ }^{\circledR}$ Virgo Electronic Compact Scale, New Delhi, India). The obtained values were expressed in grams (g).

2.7. Induction of DOX-Induced Cardiotoxicity and Treatment of Rats. Prior to commencement of the experiment, rats were randomly allotted into 7 groups of 7 rats per group such that the weight difference between and within groups was not more than $\pm 20 \%$ of the average weight of the sample population of rats used for the study. However, the choice of the therapeutic dose range of 100,200 , and $400 \mathrm{mg} / \mathrm{kg} / \mathrm{day}$ of IGESE was made based on the result of the orientation studies conducted.

Treatments of rats with distilled water, 100$400 \mathrm{mg} / \mathrm{kg} /$ day of IGESE in 5\% DMSO distilled water, $20 \mathrm{mg} / \mathrm{kg} /$ day of vitamin C (standard antioxidant drug) for 10 days, and subsequent treatment with single intraperito- neal dose $(15 \mathrm{mg} / \mathrm{kg})$ doxorubicin in $0.9 \%$ normal saline on day 11 are as indicated in Table 1.

2.8. Collection of Blood Samples. 72 hours postdoxorubicin injection, overnight fasted rats were humanely sacrificed under light inhaled diethyl ether anesthesia, and whole blood samples were collected directly from the heart with fine $21 \mathrm{G}$ injectable needle and $5 \mathrm{ml}$ syringe without causing damage to the heart tissues. The rat heart, liver, kidneys, and testes were carefully identified, harvested, and weighed.

2.9. Bioassays. Blood samples collected into $10 \mathrm{ml}$ plain sample bottles were allowed to clot at room temperature for 6 hours and then centrifuged at $5000 \mathrm{rpm}$ to separate clear sera from the clotted blood samples. The clear samples were obtained for assays of the following biochemical parameters: serum cardiac troponin I, LDH, TG, TC, and cholesterol fractions (HDL-c, LDL-c) using estimated standard bioassay procedures and commercial kits.

2.10. AI and CRI Calculation. AI was calculated as LDL - c $(\mathrm{mg} / \mathrm{dl}) \div \mathrm{HDL}-\mathrm{c}(\mathrm{mg} / \mathrm{dl})$ [44], while CRI was calculated as $\mathrm{TC}(\mathrm{mg} / \mathrm{dl}) \div \mathrm{HDL}-\mathrm{c}(\mathrm{mg} / \mathrm{dl})[45]$.

2.11. Determination of Cardiac Tissue Antioxidant Profile. After the rats were sacrificed humanely under inhaled diethyl ether, the heart was harvested en bloc. The heart was gently and carefully divided into two halves (each consisting of the atrium and ventricle) using a new surgical blade. The left half of the heart was briskly rinsed in ice-cold $1.15 \% \mathrm{KCl}$ solution in order to preserve the oxidative enzyme activities of the heart before being placed in a clean sample bottle which itself was in an ice-pack filled cooler. This is to prevent the breakdown of the oxidative stress enzymes in these organs.

Activities of cardiac tissue oxidative stress markers such as SOD, CAT, MAD, GSH, GPx, and GST were assays using methods earlier described by Olorundare et al. [42].

2.12. Histopathological Studies. The right halves of the seven randomly selected rats from each treatment and control groups were subjected to histopathological examinations; the choice of the right ventricle was based on its reported most susceptibility to doxorubicin toxicity of the four heart chambers. The dissected right heart half was briskly rinsed in normal saline and then preserved in 10\% formo-saline. It was then completely dehydrated in $100 \%$ ethanol before it was embedded in routine paraffin blocks. $4-5 \mu \mathrm{m}$ thick sections of the cardiac tissue were prepared from these paraffin blocks and stained with hematoxylin-eosin. These were examined under a photomicroscope connected to a host computer for any associated histopathological lesions.

2.13. Statistical Analysis. Data were presented as mean \pm S.E .M. of four observations for the in vitro studies and mean \pm S.D. of seven observations for the in vivo studies, respectively. Statistical analysis was done using a two-way analysis of variance followed by the Student-Newman-Keuls test on GraphPad Prism Version 5. Statistical significance was considered at $p<0.05, p<0.001$, and $p<0.0001$. 
TABLE 1: Group treatment of rats.

\begin{tabular}{|c|c|}
\hline Groups & Treatments \\
\hline Group I & $10 \mathrm{ml} / \mathrm{kg}$ of distilled water given p.o. for 10 days $+1 \mathrm{ml} / \mathrm{kg}$ of $0.9 \%$ normal saline given i.p. on day 11 \\
\hline Group II & $200 \mathrm{mg} / \mathrm{kg} /$ day of IGESE in $5 \%$ DMSO-distilled water given p.o. for 10 days $+1 \mathrm{ml} / \mathrm{kg}$ of $0.9 \%$ norma \\
\hline Group III & $\begin{array}{l}10 \mathrm{ml} / \mathrm{kg} / \text { day of distilled water given p.o. for } 10 \text { days }+15 \mathrm{mg} / \mathrm{kg} \text { of doxorubicin hydrochloride in } 0.9 \% \text { normal saline gi } \\
\text { day } 11\end{array}$ \\
\hline IV & $\begin{array}{r}20 \mathrm{mg} / \mathrm{kg} / \text { day of Vit. C dissolved in 5\% DMSO-distilled water g } \\
0.9 \% \text { normal saline }\end{array}$ \\
\hline Group V & 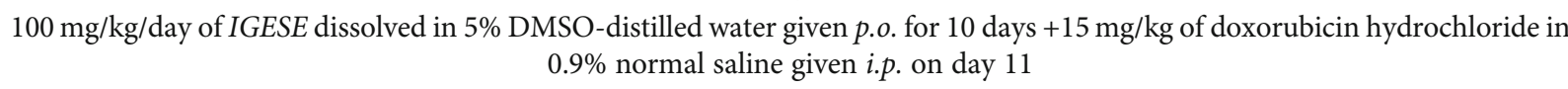 \\
\hline Group VI & $200 \mathrm{mg} / \mathrm{kg} /$ day of $I G E S E$ dissolved in 5\% DMSC \\
\hline & $400 \mathrm{mg} / \mathrm{kg} /$ day of IGESE dissolved in 5\% DMSO-distilled water given p.o. for 10 days $+15 \mathrm{mg} / \mathrm{kg}$ of doxorubicin hydrochloride in \\
\hline VII & 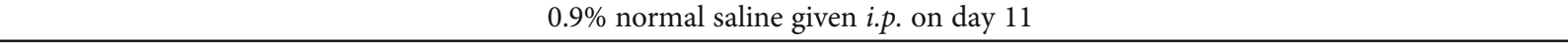 \\
\hline
\end{tabular}

\section{Results}

3.1. \% Yield. Complete extraction of Irvingia gabonensis ethanol seed extract in absolute ethanol resulted in an average yield of $4.31 \%$, which was a very dark brown, oily, and sweet-smelling paste-like residue that was soluble in methanol and ethanol but not in water.

3.2. Preliminary Qualitative Phytochemical Analysis of IGESE. This shows the presence of phenol, flavonoids, tannin, terpenoids, steroids, and reducing sugars, while saponin and phlobatannin were absent.

3.3. Preliminary Quantification of the Secondary Metabolites in IGESE. Preliminary quantitative analysis of IGESE showing the relative abundance and quantification of secondary metabolites (expressed in $\mathrm{mg} / 100 \mathrm{~g}$ of dry IGESE) shows the presence of phenol $(57.18 \pm 0.05)$, flavonoids (18.19 \pm 0.07$), \quad$ alkaloids $\quad(50.51 \pm 0.17), \quad$ steroids $(47.47 \pm 0.03)$, tannin $(41.60 \pm 0.03)$, and reducing sugars $(65.64 \pm 0.23)$ (Table 2).

3.4. Phytoscan for Secondary Metabolites in IGESE Using Gas Chromatography-Mass Spectrometry. The presence and relative abundance of fifty-six (56) major secondary metabolites in IGESE obtained through gas chromatography-mass spectrometry and phytoscan based on CAS Library search included 4,6-di-O-methyl-alpha-d-galactose (27.08\%), $n$-hexadecanoic acid (5.51\%), undecanoic acid (5.08\%), 9,12,15octadecatrienoic acid, (Z,Z,Z) (4.84\%), $\gamma$-sitosterol (4.18\%), Phytol (3.84\%), neophytadiene (3.77\%), ethyl 9,12,15-octadecatrienoate (3.65\%), stigmasterol (3.03\%), vitamin E $(2.91 \%)$, hexadecanoic acid, ethyl ester (2.51\%), Phytyl palmitate (1.92\%), campesterol (1.34\%), lupeol (1.22\%), 9,12-octadecadienoic acid $(Z, Z)(0.96 \%)$, octadecanoic acid, ethyl ester (0.91\%), lup-20(29)-en-3-one (0.84\%), $\beta$-amyrone $(0.82 \%)$, phenol $(0.82 \%)$, 1-hexacosanol $(0.77 \%)$, pyrrolidine, 1-(1cyclohexen-1-yl)-(0.71\%), triacontyl acetate $(0.66 \%)$, octadecanoic acid, 2,3-dihydroxypropyl ester (0.59\%), $\gamma$-tocopherol (0.35\%), 1,2-bis(trimethylsilyl) benzene (0.34\%), and squalene $(0.26 \%)$ (Table 3 and Figure 1$)$.
TABLE 2: Quantitative analysis of the secondary metabolites in IGESE (mg/100 g of dry extract sample).

\begin{tabular}{lc}
\hline Secondary metabolite & Quantity $(\mathrm{mg} / 100 \mathrm{~g}$ of dry extract $)$ \\
\hline Flavonoids & $18.19 \pm 0.07$ \\
Alkaloids & $50.51 \pm 0.17$ \\
Reducing sugar & $65.64 \pm 0.23$ \\
Phenols & $57.18 \pm 0.05$ \\
Steroids & $47.47 \pm 0.03$ \\
Tannin & $41.60 \pm 0.03$ \\
\hline
\end{tabular}

\subsection{In Vitro Antioxidant Profiling of IGESE}

3.5.1. Determination of DPPH Scavenging Activity of IGESE. Table 4 shows the in vitro DPPH scavenging activities of $25 \mu \mathrm{g} / \mathrm{ml}, 50 \mu \mathrm{g} / \mathrm{ml}, 75 \mu \mathrm{g} / \mathrm{ml}$, and $100 \mu \mathrm{g} / \mathrm{ml}$ of IGESE in comparison with those of corresponding doses of the standard antioxidant drug (Vit. C) used. IGESE's DPPH scavenging activities were significantly $(p<0.001$ and $p<0.0001)$ dose related at $75 \mu \mathrm{g} / \mathrm{ml}$ and $100 \mu \mathrm{g} / \mathrm{ml}$, and these were comparable to that of Vit. C (Table 4).

3.5.2. Determination of NO Scavenging Activity of IGESE. Table 5 shows the in vitro NO scavenging activities of $25 \mu \mathrm{g} / \mathrm{ml}, 50 \mu \mathrm{g} / \mathrm{ml}, 75 \mu \mathrm{g} / \mathrm{ml}$, and $100 \mu \mathrm{g} / \mathrm{ml}$ of IGESE in comparison with those of corresponding doses of the standard antioxidant drug (Vit. C). IGESE's NO scavenging activities of the extract were significantly $(p<0.001, p<0.0001)$ dose related and comparable to that of Vit. C at $75 \mu \mathrm{g} / \mathrm{ml}$ and $100 \mu \mathrm{g} / \mathrm{ml}$ of IGESE (Table 5).

3.5.3. Determination of FRAP of IGESE. Table 6 shows IGESE's in vitro ferric reducing activity power of $25 \mu \mathrm{g} / \mathrm{ml}$, $50 \mu \mathrm{g} / \mathrm{ml}, 75 \mu \mathrm{g} / \mathrm{ml}$, and $100 \mu \mathrm{g} / \mathrm{ml}$ in comparison with those of corresponding doses of the standard antioxidant drug. Again, IGESE's FRAP activities were significantly $(p<0.05$, $p<0.001, p<0.0001)$ dose dependent and comparable to that of Vit. C especially at $50 \mu \mathrm{g} / \mathrm{ml}, 75 \mu \mathrm{g} / \mathrm{ml}$, and $100 \mu \mathrm{g} / \mathrm{ml}$ of IGESE (Table 6). 
TABLE 3: Quantitative analysis of the secondary metabolites (PhytoScan) of Irvingia gabonensis ethanol seed extract (IGESE) using gas chromatography-mass spectrometry.

\begin{tabular}{|c|c|c|c|c|c|}
\hline $\mathrm{Pk} \#$ & $\mathrm{RT}$ & Area (\%) & Library/IDRef\# & CAS\# & Quality (\%) \\
\hline 1. & 4.069 & 0.1378 & Ethanol, 2-(ethylamino)- & $000110-73-6$ & 80 \\
\hline 2. & 4.906 & 0.0411 & Oxime-, methoxy-phenyl- & $1000222-86-6$ & 91 \\
\hline 3. & 5.137 & 0.1764 & 1,2-Cyclopentanedione & 003008-40-0 & 78 \\
\hline 4. & 5.455 & 0.0811 & Cyclotetrasiloxane, octamethyl- & $000556-67-2$ & 83 \\
\hline 5. & 5.721 & 0.8170 & Phenol & 000108-95-2 & 90 \\
\hline 6. & 5.905 & 0.1070 & Phenol & 000108-95-2 & 60 \\
\hline 7. & 8.291 & 0.1399 & Z,Z-7,11-Hexadecadien-1-ol & $1000131-01-4$ & 50 \\
\hline 8. & 8.458 & 0.0616 & Cyclotetrasiloxane, octamethyl- & 000556-67-2 & 64 \\
\hline 9. & 10.387 & 0.0843 & Naphthalen-4a,8a-imine, octahydro- & $005735-21-7$ & 50 \\
\hline 10. & 10.503 & 0.7119 & Pyrrolidine, 1-(1-cyclohexen-1-yl)- & 001125-99-1 & 50 \\
\hline 11. & 11.288 & 0.1380 & Cycloheptasiloxane, tetradecamethyl- & 000107-50-6 & 60 \\
\hline 12 . & 12.137 & 0.4489 & 4-Methyl-2,5-dimethoxybenzaldehyde & 004925-88-6 & 60 \\
\hline 13. & 13.125 & 5.0814 & Undecanoic acid & $000112-37-8$ & 53 \\
\hline 14. & 14.516 & 3.7713 & Neophytadiene & 000504-96-1 & 89 \\
\hline 15. & 15.088 & 27.0790 & 4,6-di-O-methyl-alpha-d-galactose & 024462-98-4 & 52 \\
\hline 16. & 15.695 & 5.5072 & n-Hexadecanoic acid & 000057-10-3 & 99 \\
\hline 17. & 15.816 & 2.5123 & Hexadecanoic acid, ethyl ester & 000628-97-7 & 98 \\
\hline 18. & 16.116 & 0.0474 & Heptadecanoic acid & 000506-12-7 & 55 \\
\hline 19. & 16.595 & 0.1190 & Heptadecanoic acid, ethyl ester & 014010-23-2 & 60 \\
\hline 20. & 16.774 & 3.8358 & Phytol & 000150-86-7 & 91 \\
\hline 21. & 17.063 & 4.8375 & 9,12,15-Octadecatrienoic acid, (Z,Z,Z)- & 000463-40-1 & 99 \\
\hline 22. & 17.185 & 3.6541 & Ethyl 9,12,15-octadecatrienoate & $1000336-77-4$ & 99 \\
\hline 23. & 17.352 & 0.9067 & Octadecanoic acid, ethyl ester & 000111-61-5 & 98 \\
\hline 24. & 17.508 & 0.3478 & 14-Pentadecenoic acid & 017351-34-7 & 86 \\
\hline 25. & 18.420 & 0.1330 & Bicyclo[3.1.1]heptan-2-one, 6,6-dimethyl- & 024903-95-5 & 55 \\
\hline 26. & 18.605 & 0.0633 & Cis-vaccenic acid & $000506-17-2$ & 91 \\
\hline 27. & 18.761 & 0.1262 & Heptadecanoic acid, ethyl ester & $014010-23-2$ & 70 \\
\hline 28. & 19.264 & 0.0555 & Cyclopentadecanone, 2-hydroxy- & 004727-18-8 & 90 \\
\hline 29. & 19.425 & 0.173 & Ethyl 9-hexadecenoate & $054546-22-4$ & 58 \\
\hline 30. & 19.599 & 0.594 & Octadecanoic acid, 2,3-dihydroxypropyl ester & 000123-94-4 & 87 \\
\hline 31. & 19.818 & 0.0961 & 1,4-benzenedicarboxylic acid, mono(1-methylethyl) ester & $1000400-56-6$ & 52 \\
\hline 32. & 19.934 & 0.0379 & Cis-9-tetradecenoic acid, heptyl ester & $1000405-20-8$ & 70 \\
\hline 33. & 20.078 & 0.1537 & Docosanoic acid, ethyl ester & 005908-87-2 & 93 \\
\hline 34. & 20.251 & 0.0452 & 18-nonadecenoic acid & 076998-87-3 & 64 \\
\hline 35. & 20.742 & 0.3606 & 1,3,12-nonadecatriene & $1000131-11-1$ & 64 \\
\hline 36. & 20.887 & 0.1046 & 2-methyl-Z,Z-3,13-octadecadienol & $1000130-90-5$ & 55 \\
\hline 37. & 21.510 & 0.2565 & Squalene & 000111-02-4 & 90 \\
\hline 38. & 22.844 & 0.3462 & $\gamma$-Tocopherol & 007616-22-0 & 98 \\
\hline 39. & 23.052 & 0.6599 & Triacontyl acetate & $041755-58-2$ & 95 \\
\hline 40. & 23.341 & 2.9085 & Vitamin E & 000059-02-9 & 99 \\
\hline 41. & 24.040 & 1.3362 & Campesterol & 000474-62-4 & 99 \\
\hline 42. & 24.277 & 3.0258 & Stigmasterol & $000083-48-7$ & 99 \\
\hline 43. & 24.427 & 0.7673 & 1-hexacosanol & 000506-52-5 & 91 \\
\hline 44. & 24.542 & 0.1545 & Hexadecanoic acid, 2-hydroxy-,methyl ester & $016742-51-1$ & 59 \\
\hline 45. & 24.750 & 4.1775 & $\gamma$-Sitosterol & $000083-47-6$ & 99 \\
\hline 46. & 24.843 & 0.8204 & $\beta$-Amyrone & 000638-97-1 & 94 \\
\hline 47. & 25.241 & 0.8408 & Lup-20(29)-en-3-one & 001617-70-5 & 97 \\
\hline 48. & 25.443 & 1.2194 & Lupeol & $000545-47-1$ & 58 \\
\hline
\end{tabular}


TABLe 3: Continued.

\begin{tabular}{|c|c|c|c|c|c|}
\hline $\mathrm{Pk} \#$ & RT & Area $(\%)$ & Library/IDRef\# & CAS\# & Quality (\%) \\
\hline 49. & 25.559 & 0.0751 & Benz[b]-1,4-oxazepine-4(5H)-thione, 2,3-dihydro-2,8-dimethyl- & $1000258-63-4$ & 50 \\
\hline 50. & 25.969 & 0.3833 & Stigmast-4-en-3-one & 001058-61-3 & 87 \\
\hline 51. & 26.431 & 0.0624 & 2,4-Cyclohexadien-1-one, 3,5-bis(1,1-dimethylethyl)-4-hydroxy- & $054965-43-4$ & 50 \\
\hline 52. & 26.829 & 1.9166 & Phytyl palmitate & $1000413-67-8$ & 96 \\
\hline 53. & 27.170 & 0.1216 & 1,4-Bis(trimethylsilyl)benzene & 013183-70-5 & 78 \\
\hline 54. & 27.592 & 0.0250 & 2,4-Cyclohexadien-1-one, 3,5-bis(1,1-dimethylethyl)-4-hydroxy- & $054965-43-4$ & 50 \\
\hline 55. & 28.463 & 0.3430 & 1,2-Bis(trimethylsilyl)benzene & 017151-09-6 & 76 \\
\hline 56. & 29.376 & 0.9577 & 9,12-Octadecadienoic acid (Z,Z)- & 000060-33-3 & 50 \\
\hline
\end{tabular}

Pk\#: peak number; RT: retention time; Area\%: percentage area covered; Library/ID Ref\#: library/identification number; CAS\#: chemical abstract scheme number.

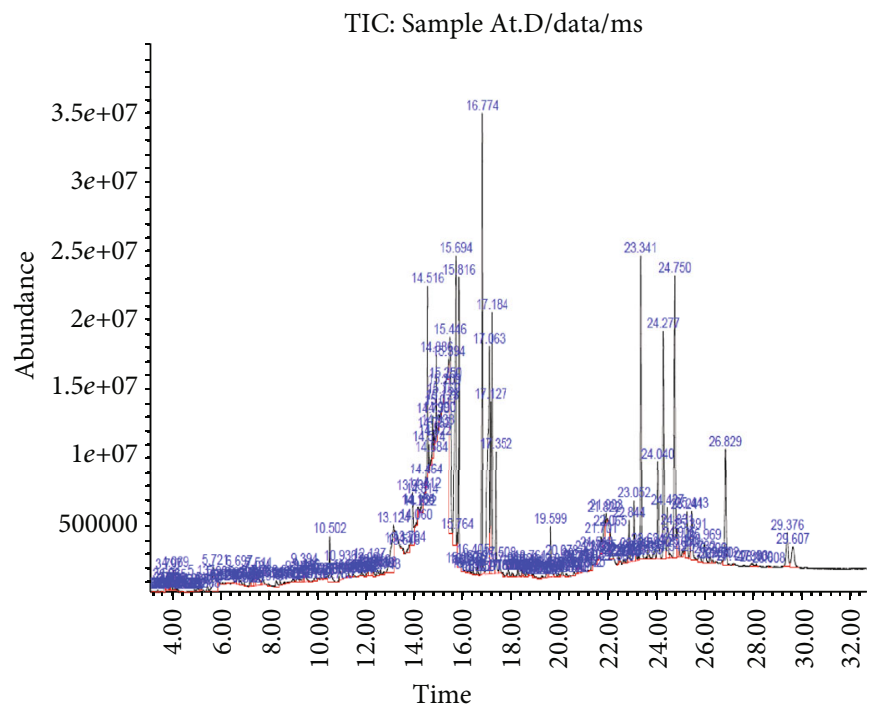

FIGURE 1: GC-MS analysis showing the relative abundance of the secondary metabolites in IGESE.

TABLE 4: In vitro DPPH scavenging activity (\% inhibition) of 25$100 \mu \mathrm{g} / \mathrm{ml}$ of IGESE and Vit. C.

\begin{tabular}{lcccc}
\hline \multirow{2}{*}{ Drug } & \multicolumn{4}{c}{ Graded doses } \\
& $25 \mu \mathrm{g} / \mathrm{ml}$ & $50 \mu \mathrm{g} / \mathrm{ml}$ & $75 \mu \mathrm{g} / \mathrm{ml}$ & $100 \mu \mathrm{g} / \mathrm{ml}$ \\
\hline IGESE & $14.59 \pm 0.31$ & $43.53 \pm 0.19$ & $67.98 \pm 0.38^{\mathrm{b}}$ & $75.44 \pm 0.51^{\mathrm{c}}$ \\
Vit. C & $45.06 \pm 0.28$ & $56.55 \pm 0.55^{\mathrm{a}}$ & $76.92 \pm 0.31^{\mathrm{c}}$ & $89.83 \pm 0.21^{\mathrm{c}}$ \\
\hline $\begin{array}{l}\text { a, b, } \text { and }^{\mathrm{c}} \text { represent significant increases at } p<0.05, p<0.001, \text { and } p<0.0001 \\
\text { respectively, when compared to the baseline value at } 25 \mu \mathrm{g} / \mathrm{ml} .\end{array}$
\end{tabular}

TABLE 5: In vitro nitric oxide (NO) scavenging activity of 25$100 \mu \mathrm{g} / \mathrm{ml}$ of IGESE and Vit. C.

\begin{tabular}{lcccc}
\hline \multirow{2}{*}{ Drug } & $25 \mu \mathrm{g} / \mathrm{ml}$ & $50 \mu \mathrm{g} / \mathrm{ml}$ & $75 \mu \mathrm{g} / \mathrm{ml}$ & $100 \mu \mathrm{g} / \mathrm{ml}$ \\
\hline IGESE & $13.55 \pm 0.70$ & $39.98 \pm 0.70$ & $68.39 \pm 0.32^{\mathrm{b}}$ & $77.09 \pm 0.13^{\mathrm{c}}$ \\
Vit. C & $47.89 \pm 0.14$ & $63.09 \pm 0.24^{\mathrm{b}}$ & $76.07 \pm 0.47^{\mathrm{c}}$ & $84.91 \pm 0.31^{\mathrm{c}}$ \\
\hline $\begin{array}{l}\text { a, b, and }{ }^{\mathrm{c}} \text { represent significant increases at } p<0.05, p<0.001 \text {, and } p<0.0001 \\
\text { when compared to the baseline value at } 25 \mu \mathrm{g} / \mathrm{ml} .\end{array}$
\end{tabular}

TABLE 6: In vitro FRAP activities of $25-100 \mu \mathrm{g} / \mathrm{ml}$ of IGESE and Vit. C.

\begin{tabular}{lcccc}
\hline \multirow{2}{*}{ Drug } & \multicolumn{4}{c}{ Graded doses } \\
& $25 \mu \mathrm{g} / \mathrm{ml}$ & $50 \mu \mathrm{g} / \mathrm{ml}$ & $75 \mu \mathrm{g} / \mathrm{ml}$ & $100 \mu \mathrm{g} / \mathrm{ml}$ \\
\hline IGESE & $0.08 \pm 0.00$ & $0.13 \pm 0.04^{\mathrm{a}}$ & $0.28 \pm 0.00^{\mathrm{b}}$ & $0.48 \pm 0.00^{\mathrm{c}}$ \\
Vit. C & $0.24 \pm 0.00$ & $0.38 \pm 0.00^{\mathrm{b}}$ & $0.48 \pm 0.00^{\mathrm{c}}$ & $0.63 \pm 0.00^{\mathrm{c}}$ \\
\hline
\end{tabular}

a, b, and ${ }^{\mathrm{c}}$ represent significant increases at $p<0.05, p<0.001$, and $p<0.0001$, respectively, when compared to the baseline value at $25 \mu \mathrm{g} / \mathrm{ml}$.

3.6. Effect of IGESE on the Cardiac Tissue Oxidative Stress Markers (GSH, GST, GPx, SOD, CAT, and MDA) of DOXTreated Rats. Intraperitoneal injection of DOX to rats resulted in significant $(p<0.05, p<0.001$, and $p<0.0001)$ decreased activities of SOD, CAT, GPx, GST, and GSH levels while significantly increasing $(p<0.001)$ MDA activities (Table 7). However, oral pretreatment with IGESE significantly $(p<0.05, p<0.001$, and $p<0.0001)$ attenuated the alterations in the activities of these cardiac tissue enzyme markers. Similarly, IGESE pretreatment significantly $(p<0.001$ and $p<0.0001)$ and dose dependently reduced MDA levels (Table 7). 
TABLe 7: Antioxidant enzyme activities of $100-400 \mathrm{mg} / \mathrm{kg} /$ day of IGESE in DOX-treated rat cardiac tissue.

\begin{tabular}{|c|c|c|c|c|c|c|}
\hline \multirow{2}{*}{ Groups } & \multicolumn{6}{|c|}{ Antioxidant parameters } \\
\hline & GSH & GST & GPx & SOD & CAT & MDA \\
\hline $\bar{I}$ & $18.8 \pm 1.6$ & $1.6 \pm 0.2$ & $1.2 \pm 0.1$ & $9.5 \pm 1.8$ & $43.6 \pm 4.7$ & $4.3 \pm 0.5$ \\
\hline II & $20.4 \pm 0.6$ & $2.7 \pm 0.2^{\mathrm{b}+}$ & $2.0 \pm 0.2$ & $10.4 \pm 1.2$ & $62.7 \pm 4.4$ & $6.0 \pm 0.5$ \\
\hline III & $14.8 \pm 0.8^{\mathrm{b}-}$ & $1.1 \pm 0.2^{\mathrm{a}-}$ & $1.0 \pm 0.1^{\mathrm{a}-}$ & $6.9 \pm 0.6^{\mathrm{b}-}$ & $16.7 \pm 2.3^{c-}$ & $12.8 \pm 1.0^{c+}$ \\
\hline IV & $21.3 \pm 1.3^{\mathrm{e}+\mathrm{e}}$ & $2.6 \pm 0.3^{\mathrm{e}+\mathrm{e}}$ & $2.4 \pm 0.2^{\mathrm{e}+, \mathrm{e}}$ & $11.5 \pm 1.5^{\mathrm{e}+\mathrm{e}}$ & $51.4 \pm 5.2^{\mathrm{d}+\mathrm{d}}$ & $5.2 \pm 0.5^{\mathrm{e}-}$ \\
\hline $\mathrm{V}$ & $17.0 \pm 1.4^{\mathrm{d}}$ & $2.0 \pm 0.2^{\mathrm{d}}$ & $1.3 \pm 0.1$ & $11.1 \pm 1.5^{\mathrm{d}+, \mathrm{d}}$ & $54.2 \pm 6.5^{\mathrm{d}+\mathrm{d}}$ & $5.3 \pm 0.6^{\mathrm{e}-}$ \\
\hline VI & $19.6 \pm 1.8^{\mathrm{d}+, \mathrm{d}}$ & $2.4 \pm 0.1^{\mathrm{e}+\mathrm{e}}$ & $2.3 \pm 0.3^{\mathrm{e}+\mathrm{e}}$ & $12.8 \pm 1.4^{\mathrm{e}+\mathrm{e}}$ & $56.6 \pm 4.3^{\mathrm{d}+\mathrm{d}}$ & $3.9 \pm 0.4^{\mathrm{f}-}$ \\
\hline VII & $24.7 \pm 1.3^{\mathrm{e}+\mathrm{e}}$ & $3.0 \pm 0.4^{\mathrm{f}+\mathrm{f}}$ & $3.3 \pm 0.4^{\mathrm{f}+\mathrm{f}}$ & $15.4 \pm 1.6^{\mathrm{e}+\mathrm{e}}$ & $78.7 \pm 6.9^{\mathrm{f}+\mathrm{f}}$ & $3.5 \pm 0.4^{\mathrm{f}-}$ \\
\hline
\end{tabular}

${ }^{\mathrm{b}+}$ represents a significant increase at $p<0.001$ when compared to untreated negative (normal) control (Group I) values; ${ }^{\mathrm{c}+}$ represents a significant increase at $p<0.0001$ when compared to IGESE-only treated (Group II) values; ${ }^{\mathrm{a}-\mathrm{b}-\text {-, }}$ and $^{\mathrm{c}-}$ represent significant decreases at $p<0.05, p<0.001$, and $p<0.0001$, respectively, when compared to Groups I values; ${ }^{\mathrm{d}+}$ and ${ }^{\mathrm{e}+}$ represent significant increases at $p<0.001$ and $p<0.0001$, respectively, when compared to untreated positive control (DOX-only treated, Group III) values; while ${ }^{\mathrm{e}-}$ and ${ }^{\mathrm{f}-}$ represent significant decreases at $p<0.001$ and $p<0.0001$, respectively, when compared to untreated positive control (DOX-treated only, Group III) values, respectively. ${ }^{\mathrm{d}, \mathrm{e}}{ }^{\mathrm{a}}$ and ${ }^{\mathrm{f}}$ represent significant increases at $p<0.05, p<0.001$, and $p<0.0001$, respectively, when compared to untreated positive control (DOX-treated only, Group III).

\subsection{Effect of IGESE on Cardiac Marker Enzymes (cTnI and} $L D H)$ of DOX-Treated Rats. Single intraperitoneal injection of DOX resulted in significant $(p<0.0001)$ increases in the serum LDH and cTnI levels when compared to that of untreated negative control (Group I) values (Table 8). However, with oral pretreatments with $100-400 \mathrm{mg} / \mathrm{kg} /$ day of IGESE significantly attenuated $(p<0.05, p<0.001$, and $p<0.0001)$ increases in the serum cTnI and LDH levels dose dependently (Table 8), and these attenuations were comparable to that induced by oral pretreatment with $20 \mathrm{mg} / \mathrm{kg} / \mathrm{day}$ of Vit. C (Table 8).

3.8. Effect of IGESE on the Serum Lipids (TG, TC, HDL-c, $L D L-c)$ Level of DOX-Treated Rats. Acute intraperitoneal DOX injection resulted in significant $(p<0.05)$ decreases in the serum TG, significantly $(p<0.001)$ increased serum TC and LDL-c while inducing insignificant $(p>0.05)$ alterations in the serum HDL-c level (Table 9). However, with 100$400 \mathrm{mg} / \mathrm{kg} /$ day of IGESE oral pretreatment, there were significant $(p<0.05$ and $p<0.0001)$ dose-related increases in the serum TG and HDL-c concentrations, while there were significant $(p>0.05$ and $p<0.001)$ decreases in the serum TC and LDL-c concentrations when compared to DOX-only treated rats (Table 9). Oral pretreatment with $20 \mathrm{mg} / \mathrm{kg} /$ day of vitamin C elicited similar effects on the measured serum lipids parameters (Table 9).

\subsection{Effect of Oral IGESE Pretreatment on Cardiovascular Risk} Indices (AI and CRI) of DOX-Treated Rats. Acute intraperitoneal injections with DOX resulted in significant $(p<0.001)$ increases in the AI and CRI values when compared to Groups I and II values (Table 10). However, with oral pretreatment with $100-400 \mathrm{mg} / \mathrm{kg} /$ day of IGESE, there were significant $(p<0.05, p<0.001$, and $p<0.0001)$ dose-related decreases in the AI and CRI values with similar effect induced by oral pretreatments with $20 \mathrm{mg} / \mathrm{kg} /$ day of Vit. C (Table 10).

3.10. Histopathological Studies of the Effect of IGESE Oral Pretreatment on DOX-Intoxicated Treated Heart. Figure 2 is a photomicrograph of a cross-sectional representative of DOX-only treated heart showing myocyte congestion and
TABLE 8: Effect of 100-400 mg/kg/day of IGESE on serum LDH and cardiac troponin I (cTnI) levels in DOX-intoxicated rats.

\begin{tabular}{lcc}
\hline Treatment groups & LDH $(\mathrm{U} / \mathrm{L})$ & $\mathrm{cTnI}(\mathrm{ng} / \mathrm{ml})$ \\
\hline I & $4347 \pm 596.4$ & $3.4 \pm 1.1$ \\
II & $4338 \pm 238.1$ & $3.7 \pm 1.1$ \\
III & $8151 \pm 441.0^{\mathrm{c}+}$ & $40.5 \pm 3.5^{\mathrm{c}+}$ \\
IV & $4887 \pm 217.5^{\mathrm{a}-}$ & $11.4 \pm 3.5^{\mathrm{c}-}$ \\
V & $4737 \pm 260.2^{\mathrm{a}-}$ & $25.5 \pm 3.3^{\mathrm{a}-}$ \\
VI & $4188 \pm 229.2^{\mathrm{b}-}$ & $19.8 \pm 2.4^{\mathrm{b}-}$ \\
VII & $3679 \pm 346.1^{\mathrm{c}-}$ & $14.8 \pm 1.1^{\mathrm{c}-}$ \\
\hline
\end{tabular}

${ }^{\mathrm{c}+}$ represents a significant increase at $p<0.0001$ when compared to untreated normal control (Group I) and IGESE only treated (Group II) values, while ${ }^{\mathrm{a}-\text {, }}$ ${ }^{\mathrm{b}-}$ and $^{\mathrm{c}-}$ represent significant decreases at $p<0.05, p<0.001$, and $p<0.0001$, respectively, when compared to DOX-only treated (Group III) values, respectively.

antemortem coronary microthrombi when compared to untreated normal (Figure 3) and IGESE-only treated heart tissues with normal cardiac architecture (Figure 4). However, pretreatment with varying doses of IGESE resulted in doserelated improvements in the histological distortions induced by DOX especially at $200 \mathrm{mg} / \mathrm{kg} /$ day (Figure 5) and $400 \mathrm{mg} / \mathrm{kg} /$ day of IGESE (Figure 6); although, histological features of vascular congestion were still seen with $100 \mathrm{mg} / \mathrm{kg} / \mathrm{day}$ of IGESE oral pretreatment (Figure 7). On the contrary, there were histological features of persistent coronary microthrombi in rat heart pretreated with $20 \mathrm{mg} / \mathrm{kg} /$ day of Vit. C, indicating the lingering DOX-induced histological lesions, even with the standard antioxidant drug (Figure 8).

\section{Discussion}

The clinical use of doxorubicin in the management of solid and hematological cancers has been widely limited by its off-target severe cardiotoxicity which manifests biochemically by elevation of serum enzyme markers of cardiotoxicity. The diagnostic serum marker enzymes of cardiotoxicity are 
TABLE 9: Effect of 100-400 mg/kg/day of IGESE on complete serum lipid profile.

\begin{tabular}{lcccc}
\hline Groups & TG(mmol/l) & TC $(\mathrm{mmol} / \mathrm{l})$ & Serum lipids & \\
I & $1.2 \pm 0.1$ & $2.0 \pm 0.1$ & HDL-c(mmol/l) & $0.7 \pm 0.0$ \\
II & $1.1 \pm 0.1$ & $1.8 \pm 0.1$ & $0.6 \pm 0.0$ & $0.6 \pm 0.1$ \\
III & $0.9 \pm 0.1^{\mathrm{a}-}$ & $2.7 \pm 0.3^{\mathrm{c}+}$ & $0.7 \pm 0.0$ & $1.6 \pm 0.2^{\mathrm{c}+}$ \\
IV & $1.2 \pm 0.1^{\mathrm{d}+}$ & $1.4 \pm 0.2^{\mathrm{f}-}$ & $0.8 \pm 0.1^{\mathrm{a}+}$ & $0.4 \pm 0.2^{\mathrm{f}-}$ \\
V & $1.0 \pm 0.2$ & $2.4 \pm 0.2^{\mathrm{d}-}$ & $0.8 \pm 0.1^{\mathrm{a}+}$ & $1.2 \pm 0.1^{\mathrm{d}-}$ \\
VI & $1.3 \pm 0.2^{\mathrm{d}+}$ & $2.3 \pm 0.2^{\mathrm{d}-}$ & $0.9 \pm 0.1^{\mathrm{b}+}$ & $1.1 \pm 0.2^{\mathrm{d}-}$ \\
VII & $1.5 \pm 0.0^{\mathrm{e}+}$ & $1.6 \pm 0.1^{\mathrm{f}-}$ & $0.6 \pm 0.0$ & $0.6 \pm 0.1^{\mathrm{f}-}$ \\
\hline
\end{tabular}

${ }^{\mathrm{a}-}$ represents a significant decrease at $p<0.05$ when compared to (Groups I and II) values, while ${ }^{\mathrm{c}}$ represents a significant increase at $p<0.0001$ when compared to Groups I and II values; ${ }^{\mathrm{d}-}$ and ${ }^{\text {f- }}$ represent significant decreases at $p<0.05$ and $p<0.0001$, respectively, when compared to DOX-only treated (Group III) values; ${ }^{\mathrm{d}+}$ and ${ }^{\mathrm{e}+}$ represent significant increases at $p<0.05$ and $p<0.001$, respectively, when compared to DOX-only treated (Group III) values.

TABLE 10: Effect of $100-400 \mathrm{mg} / \mathrm{kg} /$ day of IGESE on cardiovascular risk indices (atherogenic index (AI) and coronary risk index (CRI)) values in DOX-intoxicated rats.

\begin{tabular}{lcc}
\hline Treatment groups & $\mathrm{TC} \div \mathrm{HDL}-\mathrm{c}(\mathrm{AI})$ & $\mathrm{LDL}-\mathrm{c} \div \mathrm{HDL}-\mathrm{c}(\mathrm{CRI})$ \\
\hline I & $2.83 \pm 0.05$ & $1.05 \pm 0.07$ \\
II & $2.86 \pm 0.12$ & $1.11 \pm 0.15$ \\
III & $3.85 \pm 0.19^{\mathrm{b}+}$ & $2.28 \pm 0.20^{\mathrm{c}+}$ \\
IV & $1.88 \pm 0.39^{\mathrm{a}-}$ & $0.64 \pm 0.33^{\mathrm{c}-}$ \\
V & $3.10 \pm 0.23^{\mathrm{a}-}$ & $1.51 \pm 0.16^{\mathrm{a}-}$ \\
VI & $2.56 \pm 0.27^{\mathrm{b}-}$ & $1.30 \pm 0.27^{\mathrm{b}-}$ \\
VII & $2.62 \pm 0.18^{\mathrm{b}-}$ & $0.98 \pm 0.16^{\mathrm{c}-}$ \\
\hline
\end{tabular}

$\mathrm{b}^{\mathrm{b}}$ and ${ }^{\mathrm{c}+}$ represent significant increases at $p<0.001$ and $p<0.0001$, respectively, when compared to Groups I and II values, respectively, while a-, b-, and ${ }^{\mathrm{c}^{-}}$represent significant decreases at $p<0.05, p<0.001$, and $p<$ 0.0001 , respectively, when compared to untreated positive control (DOXonly treated) (Group III) values, respectively.

AST, ALT, CK-MB, LDH, and cTnI which leak from cardiac tissue damage to the bloodstream due to their tissue specificity and serum catalytic activity [46]. DOX administration may result in the damage to the myocardial cell membrane or make myocytes more permeable, resulting in the leakage of the diagnostic cardiac enzyme markers cardiac AST, ALT, CK-MB, LDH, and CTnI into the bloodstream and their high circulating levels. In the present study, DOX-mediated cardiotoxicity was fully established as evidenced by the profound elevations in the serum cTnI and LDH levels which is in complete agreement with previous studies [47-52]. With oral IGESE pretreatments, the serum levels of cTnI and LDH were profoundly attenuated toward normal serum level indicating the ameliorative potential of IGESE in DOX-mediated cardiotoxicity. These effects were probably mediated through high antioxidant and/or free radical scavenging activities of IGESE on the myocardium, thus reducing the damaging effects of DOX to the cardiac muscle fibers, subsequently minimizing the leakage of such enzymes in the serum. Similarly, ROS-mediated mechanism is one of the proposed DOXmediated cardiotoxicity mechanisms, leading to oxidative

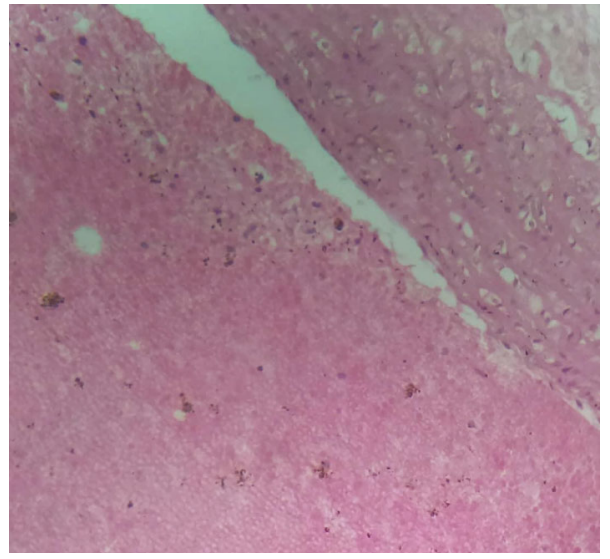

FIgURE 2: A cross-sectional representative of $15 \mathrm{mg} / \mathrm{kg}$ of DOX-only intoxicated rat cardiac tissue showing antemortem coronary artery microthrombi and congested cardiomyocytes suggestive of coronary intravascular thrombosis $(\times 400$ magnification, Hematoxylin and Eosin stain).

stress that causes cardiomyopathy [53]. Oxidative stress has been reported to increase lipid peroxidation as indicated by an increase in MDA levels and altered enzymatic and nonenzymatic antioxidant systems [54, 55]. In this study, MDA level was profoundly increased by DOX treatment, while DOX treatment also suppressed the cardiac tissue activities of SOD, CAT, GPx, GST, and GSH levels in the treated rats in agreement with other studies. These altered biochemical alterations were supported by histological lesions characterized by myocyte congestion and coronary intravascular microthrombi formation. DOX has been previously reported to profoundly reduce vascular blood flow, disintegrate vascular endothelium, and promote GPIIb/IIIa-mediated platelet adhesion and aggregation, all resulting in microthrombi formation [5658]. The fact that IGESE prevented microthrombi formation in DOX-treated coronary vasculature as evidenced by histopathological results of this study highlighted the possible inherent antithrombotic potential of IGESE; although, further studies are still needed in this respect in order to validate this hypothesis. However, IGESE profoundly attenuated 


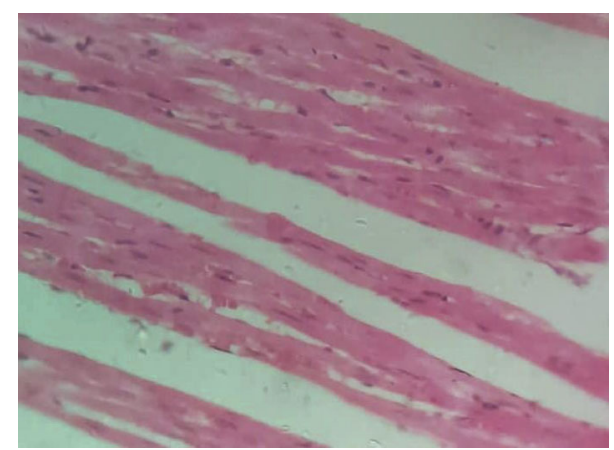

FIgURE 3: A cross-sectional representative of normal rat cardiac tissue showing normal cardiac histoarchitecture $(\times 400$ magnification, Hematoxylin and Eosin stain).

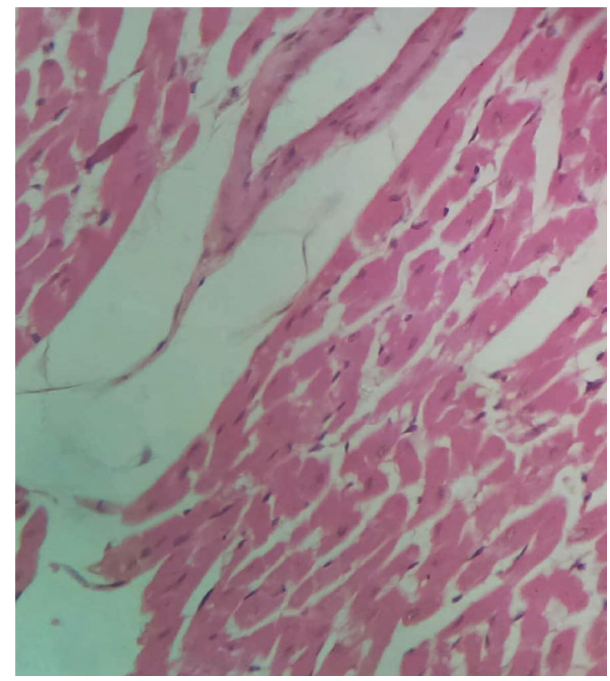

Figure 4: A cross-sectional representative of $200 \mathrm{mg} / \mathrm{kg} /$ day of IGESE-only pretreated rat cardiac tissue showing normal cardiac histoarchitecture $(\times 400$ magnification, Hematoxylin and Eosin stain).

significant alterations in the cardiac tissue oxidative markers whose activities were significantly suppressed by DOX intoxication. IGESE has the tendency to neutralize ROS like superoxide radicals, singlet oxygen, nitric oxide, and peroxynitrite, thereby reducing the damage to lipid membranes [39]. Similarly, oral IGESE pretreatments profoundly improved and reversed the DOX-induced histological lesions especially at $200 \mathrm{mg} / \mathrm{kg} /$ day and $400 \mathrm{mg} / \mathrm{kg} /$ day of IGESE pretreatments.

The effects of DOX on serum lipids are also significant. DOX has been reported to cause hyperlipidemia (which include increased serum cholesterol, triglyceride, LDL-c, and FFAs) [59-64] and increases cardiovascular disease risk [65]. This hyperlipidemia is thought to be mediated via downregulation of PPAR- $\gamma$ and subsequently affect GLUT4 and FAT/CD36 expression resulting in glucose and fatty acid transporters expression and causing hyperglycemia and hyperlipidemia [65]. Irvingia gabonensis seeds have been reported to induce weight loss, antihyperlipidemia, and reduced cardiovascular disease risk

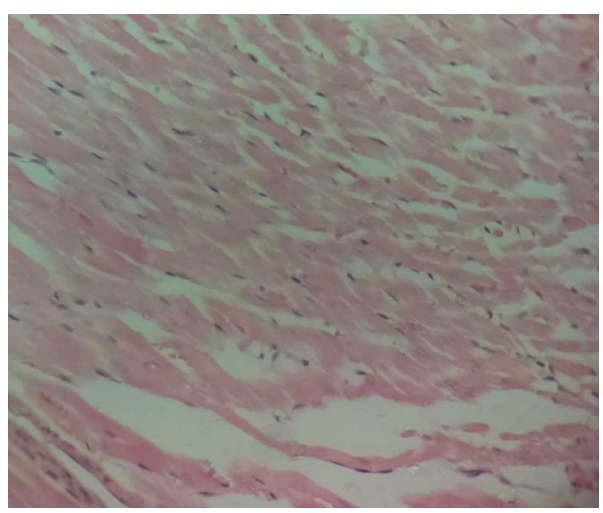

FIgURE 5: A cross-sectional representative of $200 \mathrm{mg} / \mathrm{kg}$ of IGESE pretreated, DOX intoxicated rat cardiac tissue showing mildly congested cardiomyocytes $(\times 400$ magnification, Hematoxylin and Eosin stain).

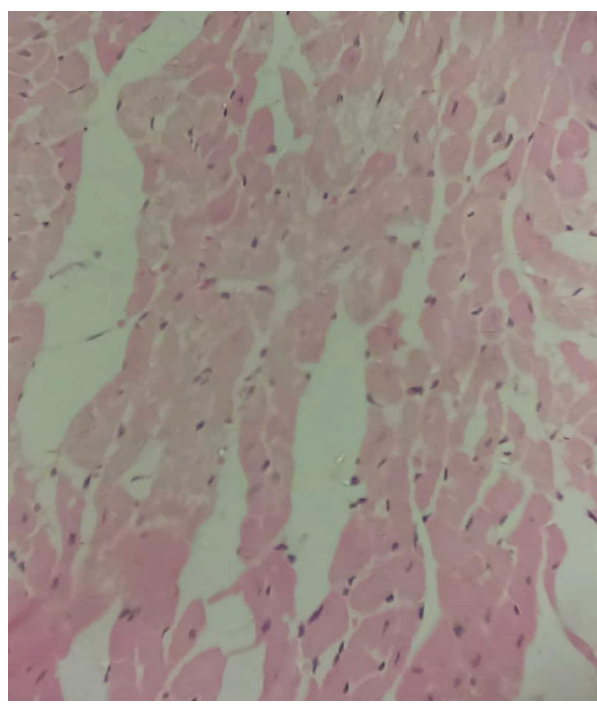

FIgURE 6: A cross-sectional representative of $400 \mathrm{mg} / \mathrm{kg}$ of IGESE pretreated, DOX intoxicated rat cardiac tissue showing normal cardiac histoarchitecture $(\times 400$ magnification, Hematoxylin and Eosin stain).

factors in both animal [59-64] and human studies [6672] which were reportedly mediated via downregulation of the PPAR- $\gamma$ and leptin genes and upregulation of the adiponectin gene mechanisms [67]. Thus, the results of this study are in tandem with those of earlier studies.

The GC-MS analysis and phytoscan of IGESE are also notably significant. IGESE is shown to contain high contents of 4,6-di-O-methyl-alpha-d-galactose, $n$-hexadecanoic acid, undecanoic acid, 9,12,15-octadecatrienoic acid, $\gamma$-sitosterol, phytol, neophytadiene, ethyl 9,12,15-octadecatrienoate, stigmasterol, vitamin E, hexadecanoic acid ethyl ester, Phytyl palmitate, campesterol, and lupeol. Phytosterols such as sitosterol, stigmasterol, campesterol, and phytols have been reported to effectively mitigate lipid peroxidation through antioxidant and free radical scavenging mechanisms and physically stabilize cell membrane [73] as well as effectively 


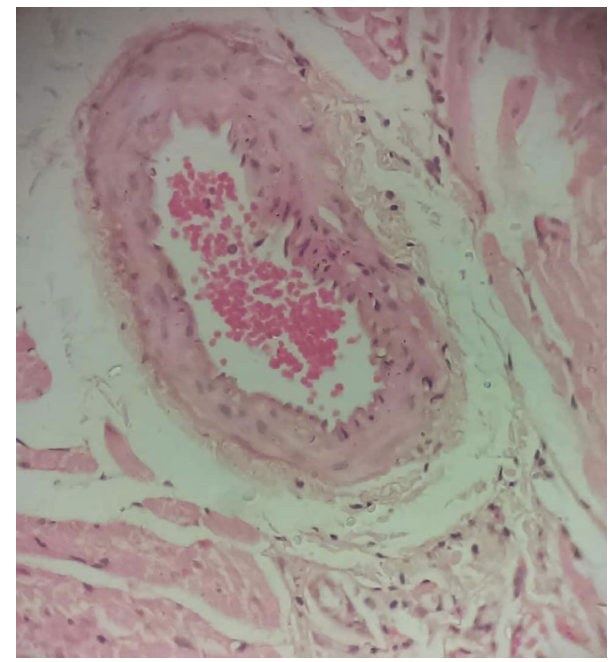

FIgURE 7: A cross-sectional representative of $100 \mathrm{mg} / \mathrm{kg} /$ day of IGESE-pretreated, DOX-intoxicated cardiac tissue showing mildto-moderate vascular congestion but normal myocardiocytes ( $\times 400$ magnification, Hematoxylin-Eosin stain).

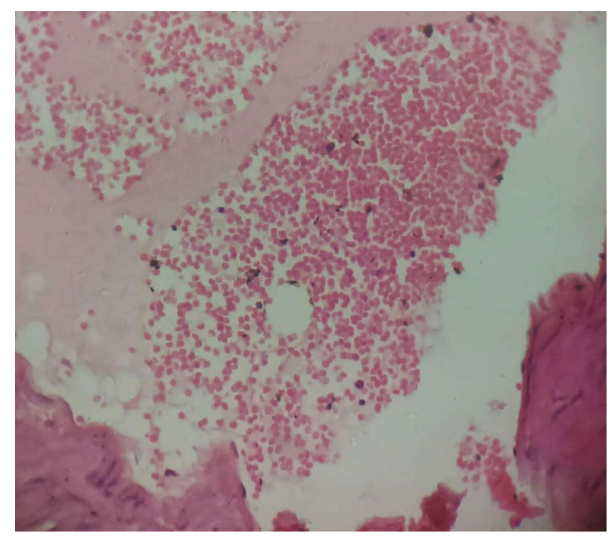

Figure 8: A cross-sectional representative of $20 \mathrm{mg} / \mathrm{kg} /$ day of vitamin $\mathrm{C}$ pretreated, DOX intoxicated rat cardiac tissue showing mild-to-moderate antemortem coronary artery thrombus and normal cardiomyocytes suggestive of coronary intravascular thrombosis ( $\times 400$ magnification, Hematoxylin and Eosin stain).

lowered cholesterol especially the LDL-c fraction [74-78]. Similarly, stigmasterol, $\gamma$-sitosterol, lupeol, lupeol acetate, and $\alpha$-amyrin are known to exhibit other important pharmacological activities such as anticancer, anti-inflammatory, and antibacterial activities [79]. Lupeol in particular is known to mediate anti-inflammatory, antimicrobial, antiprotozoal, antiproliferative, anti-invasive, antiangiogenic, and cholesterol-lowering activities [79, 80]. Phytol is an important diterpene that possesses antimicrobial, antioxidant, and anticancer activities [81, 82]. Hexadecanoic acid is known to exhibit strong antimicrobial and antiinflammatory activity [83]. Squalene, a triterpene, is a natural antioxidant [84], possessing various other pharmacological properties including antimicrobial property $[85,86]$. Neophytadiene is a good analgesic, antipyretic, anti-inflamma- tory, antimicrobial, and antioxidant compound [87, 88]. Thus, the presence of stigmasterol, $\gamma$-sitosterol, lupeol, phytols, and neophytadiene in high amounts in IGESE could be responsible for the cholesterol-lowering, antioxidant, and antilipiperoxidation activities of IGESE in DOX-mediated cardiotoxic rats. Similarly, flavonoids, steroids, cardiac glycosides, tannin, and saponin have been reported to elicit antithrombotic activities [89-91], and more specifically, plant-derived sitosterol has been reported to have anticoagulant and thrombus-preventing activities in mice [78, 92, 93]. Thus, the presence of these phytochemicals especially steroids and tannin in high amounts in IGESE could be responsible for the observed antithrombotic action of IGESE in DOX-intoxicated rats.

\section{Conclusion}

Overall, results of this study showed that IGESE effectively attenuated DOX-mediated cardiotoxicity and its cardioprotective activities were mediated via antioxidant, free radical scavenging, antilipoperoxidation, and antithrombotic mechanisms.

\section{Abbreviations}

AI: $\quad$ Atherogenic index

ALT: $\quad$ Alanine transaminase

AST: $\quad$ Aspartate transaminase

CAT: $\quad$ Catalase

CK-MB: Creatine kinase-MB

CRI: $\quad$ Coronary artery index

DMSO: Dimethyl sulfoxide

DNA: $\quad$ Deoxyribonucleic acid

DOX: Doxorubicin

DPPH: 1,1-diphenyl-2-picrylhydrazyl

FAT/CD36: Fatty acid translocase

FFAs: $\quad$ Free fatty acids

FRAP: $\quad$ Ferric reducing activity power

GC-MS: Gas chromatography mass spectrometer

GLUT4: Glucose transporter member 4

GPIIb/IIIa: Glycoprotein IIb/IIIa

GPx: $\quad$ Glutathione peroxidase

GSH: $\quad$ Reduced glutathione

GST: $\quad$ Glutathione S-transferase

HDL-c: High density lipoprotein cholesterol

i.p.: Intraperitoneal

IGESE: Irginvia gabonensis ethanol seed extract

KCl: $\quad$ Potassium chloride

LDH: $\quad$ Lactate dehydrogenase

LDL-c: $\quad$ Low density lipoprotein cholesterol

MDA: $\quad$ Malondialdehyde

NO: $\quad$ Nitric oxide

p.o.: $\quad$ Per os

PPAR $\gamma: \quad$ Peroxisome proliferator-activator receptor

ROS: $\quad$ Reactive oxygen species

rpm: Revolution per minute

S.E.M.: $\quad$ Standard error of the mean

SOD: $\quad$ Superoxidase dismutase 


$\begin{array}{ll}\text { TC: } & \text { Total cholesterol } \\ \text { TG: } & \text { Triglyceride } \\ \text { UERC: } & \text { UNILORIN ethics and research committee } \\ \text { UNILORIN: } & \text { University of Ilorin } \\ \text { Vit. C: } & \text { Vitamin C. }\end{array}$

\section{Data Availability}

Answer: Yes. Comment

\section{Conflicts of Interest}

The authors have none to declare.

\section{Authors' Contributions}

Olufunke Olorundare designed the experimental protocol for this study and was involved in the manuscript writing; Adejuwon Adeneye supervised the research, analyzed data, and wrote the manuscript; Akinyele Akinsola and Olalekan Agede are postgraduate students in Olufunke Olorundare's laboratory that performed the laboratory research under supervision; Phillip Kolo was part of the protocol design and read through the manuscript; Ikechukwu Okoye prepared the cardiac tissue slides; Sunday Soyemi and Alban Mgbehoma independently read and interpreted the cardiac tissue slides; Ralph Albrecht and Hasan Mukhtar are our collaborators in the U.S.A. who read through the manuscript.

\section{Acknowledgments}

The authors deeply appreciate the technical assistance provided by the Laboratory Manager, Dr. Sarah John-Olabode, and other staff of the Laboratory Services, AFRIGLOBAL MEDICARE, Mobolaji Bank Anthony Branch Office, Ikeja, Lagos, Nigeria, in assaying for the serum cardiac biomarkers and lipid profile. Similarly, the technical support of staff of LASUCOM Animal House, for the care of the Experimental Animals used for this study and Mr. Sunday Adenekan of BIOLIFE CONSULTS in the area of oxidative stress markers analysis are much appreciated. This research was funded by the Tertiary Education Trust Fund (TETFUND) Nigeria, through its National Research Fund (TETFUND/NRF/UIL/ILORIN/STI/VOL.1/B2.20.12) as a collaborative research award to Professors Olufunke Olorundare, Phillip Kolo, and Hasan Mukhtar.

\section{References}

[1] P. A. Henriksen, "Anthracycline cardiotoxicity: an update on mechanisms, monitoring and prevention," Heart, vol. 104, no. 12, pp. 971-977, 2018.

[2] Y. Pommier, E. Leo, H. Zhang, and C. Marchand, "DNA topoisomerases and their poisoning by anticancer and antibacterial drugs," Chemistry \& Biology, vol. 17, no. 5, pp. 421-433, 2010.

[3] O. Tacar, P. Sriamornsak, and C. R. Dass, "Doxorubicin: an update on anticancer molecular action, toxicity and novel drug delivery systems," The Journal of Pharmacy and Pharmacology, vol. 65, no. 2, pp. 157-170, 2013.
[4] B. Pang, X. Qiao, L. Janssen et al., "Drug-induced histone eviction from open chromatin contributes to the chemotherapeutic effects of doxorubicin," Nature Communications, vol. 4, no. 1, article 1908, 2013.

[5] J. Kropp, E. C. Roti Roti, A. Ringelstetter, H. Khatib, D. H. Abbott, and S. M. Salih, "Dexrazoxane diminishes doxorubicin-induced acute ovarian damage and preserves ovarian function and fecundity in mice," PLoS One, vol. 10, no. 11, article e0142588, 2015.

[6] L. A. Smith, V. R. Cornelius, C. J. Plummer et al., "Cardiotoxicity of anthracycline agents for the treatment of cancer: systematic review and meta-analysis of randomised controlled trials," BMC Cancer, vol. 10, no. 1, p. 337, 2010.

[7] P. Spallarossa, N. Maurea, C. Cadeddu et al., "A recommended practical approach to the management of anthracycline-based chemotherapy cardiotoxicity: an opinion paper of the working group on drug cardiotoxicity and cardioprotection, Italian Society of Cardiology," Journal of Cardiovascular Medicine, vol. 17, Supplement 1, pp. e84-e92, 2016.

[8] P. Menna and E. Salvatorelli, "Primary prevention strategies for anthracycline cardiotoxicity: a brief overview," Chemother$a p y$, vol. 62, no. 3, pp. 159-168, 2017.

[9] A. Engert, J. Franklin, H. T. Eich et al., "Two cycles of doxorubicin, bleomycin, vinblastine, and dacarbazine plus extendedfield radiotherapy is superior to radiotherapy alone in early favorable Hodgkin's lymphoma: final results of the GHSG HD7 trial," Journal of Clinical Oncology, vol. 25, no. 23, pp. 3495-3502, 2007.

[10] A. Brayfield, Doxorubicin in: Martindale: The Complete Drug Reference, Pharmaceutical Press, London, 2013.

[11] M. Zhao, X.-F. Ding, J.-Y. Shen, X. P. Zhang, X. W. Ding, and $\mathrm{B}$. Xu, "Use of liposomal doxorubicin for adjuvant chemotherapy of breast cancer in clinical practice," Journal of Zhejiang University. Science. B, vol. 18, no. 1, pp. 15-26, 2017.

[12] M. Magni, G. Biancon, S. Rizzitano et al., "Tyrosine kinase inhibition to improve anthracycline-based chemotherapy efficacy in T-cell lymphoma," British Journal of Cancer, vol. 121, no. 7, pp. 567-577, 2019.

[13] A. Kaczmarek, B. M. Brinkman, L. Heyndrickx, P. Vandenabeele, and D. V. Krysko, "Severity of doxorubicin-induced small intestinal mucositis is regulated by the TLR-2 and TLR-9 pathways," The Journal of Pathology, vol. 226, no. 4, pp. 598-608, 2012.

[14] S. M. Swain, F. S. Whaley, and M. S. Ewer, "Congestive heart failure in patients treated with doxorubicin: a retrospective analysis of three trials," Cancer, vol. 97, no. 11, pp. 28692879, 2003.

[15] E. A. M. Feijen, W. M. Leisenring, K. L. Stratton et al., "Derivation of anthracycline and anthraquinone equivalence ratios to doxorubicin for late-onset cardiotoxicity," JAMA Oncology, vol. 5, no. 6, pp. 864-871, 2019.

[16] M. Theodoulou and C. Hudis, "Cardiac profiles of liposomal anthracyclines: greater cardiac safety versus conventional doxorubicin?," Cancer, vol. 100, no. 10, pp. 2052-2063, 2004.

[17] K. Chatterjee, J. Zhang, N. Honbo, and J. S. Karliner, "Doxorubicin cardiomyopathy," Cardiology, vol. 115, no. 2, pp. 155$162,2010$.

[18] J. V. McGowan, R. Chung, A. Maulik, I. Piotrowska, J. M. Walker, and D. M. Yellon, "Anthracycline chemotherapy and cardiotoxicity," Cardiovascular Drugs and Therapy, vol. 31, no. 1, pp. 63-75, 2017. 
[19] M. Štěrba, O. Popelová, A. Vávrová et al., "Oxidative stress, redox signaling, and metal chelation in anthracycline cardiotoxicity and pharmacological cardioprotection," Antioxidants \& Redox Signaling, vol. 18, no. 8, pp. 899-929, 2013.

[20] N. Kalay, E. Basar, I. Ozdogru et al., "Protective effects of carvedilol against anthracycline-induced cardiomyopathy," Journal of the American College of Cardiology, vol. 48, no. 11, pp. 2258-2262, 2006.

[21] F. Cai, M. Luis, X. Lin et al., "Anthracycline-induced cardiotoxicity in the chemotherapy treatment of breast cancer: preventive strategies and treatment (Review)," Molecular and Clinical Oncology, vol. 11, no. 1, pp. 15-23, 2019.

[22] H. Kaiserová, T. Šimůnek, W. J. F. van der Vijgh, A. Bast, and E. Kvasničková, "Flavonoids as protectors against doxorubicin cardiotoxicity: role of iron chelation, antioxidant activity and inhibition of carbonyl reductase," Biochimica et Biophysica Acta (BBA) - Molecular Basis of DiseaseBiochimica et Biophysica Acta, vol. 1772, no. 9, pp. 1065-1074, 2007.

[23] G. Minotti, P. Menna, E. Salvatorelli, G. Cairo, and L. Gianni, "Anthracyclines: molecular advances and pharmacologic developments in antitumor activity and cardiotoxicity," Pharmacological Reviews, vol. 56, no. 2, pp. 185-229, 2004.

[24] F. F. Che, Y. Liu, and C. G. Xu, "Study on the effect and mechanism of dextromethionine on cardiotoxicity induced by doxorubicin," Journal of Sichuan University, vol. 41, pp. 2428,2010 .

[25] X. Gao, Z. Han, and X. Du, "Observation of the effects of dextromethine on cardiotoxicity induced by epirubicin," Chinese Journal of Cancer Prevention and Treatment, vol. 17, pp. 296-298, 2010.

[26] G. Sacco, M. Bigioni, S. Evangelista, C. Goso, S. Manzini, and C. A. Maggi, "Cardioprotective effects of zofenopril, a new angiotensin-converting enzyme inhibitor, on doxorubicininduced cardiotoxicity in the rat," European Journal of Pharmacology, vol. 414, no. 1, pp. 71-78, 2001.

[27] G. Sacco, M. Bigioni, G. Lopez, S. Evangelista, S. Manzini, and C. A. Maggi, "ACE inhibition and protection from doxorubicin-induced cardiotoxicity in the rat," Vascular Pharmacology, vol. 50, no. 5-6, pp. 166-170, 2009.

[28] A. Vavrova, H. Jansova, E. Mackova et al., "Catalytic inhibitors of topoisomerase II differently modulate the toxicity of anthracyclines in cardiac and cancer cells," PLoS One, vol. 8, no. 10, article e76676, 2013.

[29] S. Deng, T. Yan, C. Jendrny et al., "Dexrazoxane may prevent doxorubicin-induced DNA damage via depleting both topoisomerase II isoforms," BMC Cancer, vol. 14, no. 1, p. 842, 2014.

[30] H. M. Burkill, The Useful Plants of West Tropical Africa, vol. 2, Royal Botanic Gardens, Kew, London, 1985.

[31] L. Karalliedde and I. Gawarammana, Traditional Herbal Medicines - a Guide to the Safer Use of Herbal Medicines, Hammersmith Press, London, 2008.

[32] B. C. Unaeze, C. E. Ilo, C. Egwuatu, I. Orabueze, and E. Obi, "Anti-diarrhoeal effects of three Nigerian medicinal plant extracts on E.coli-induced diarrhea," International Journal of Biological and Chemical Sciences, vol. 11, no. 1, pp. 414-419, 2017.

[33] G. K. Mahunu, L. Quansa, H. E. Tahir, and A. A. Mariod, "Irvingia gabonensis: phytochemical constituents, bioactive compounds, traditional and medicinal uses," in Wild Fruits: Composition, Nutritional Value and Products, A. Mariod, Ed., Springer Cham, New York, NY, USA, 2019.
[34] J. I. Okogun, "Drug discovery through ethnobotany in Nigeria: some results," in Advances in Phytomedicine - Ethnomedicine and Drug Discovery, M. M. Iwu and J. C. Wootton, Eds., vol. 1, pp. 145-154, Elsevier, London, 2002.

[35] J. Sun and P. Chen, "Ultra high-performance liquid chromatography with high-resolution mass spectrometry analysis of African mango (Irvingia gabonensis) seeds, extract, and related dietary supplements," Journal of Agricultural and Food Chemistry, vol. 60, no. 35, pp. 8703-8709, 2012.

[36] F. M. Awah, P. N. Uzoegwu, P. Ifeonu et al., "Free radical scavenging activity, phenolic contents and cytotoxicity of selected Nigerian medicinal plants," Food Chemistry, vol. 131, no. 4, pp. 1279-1286, 2012.

[37] O. A. Wolfe and U. F. Ijeoma, "Effects of aqueous extracts of Irvingia gabonensis seeds on the hormonal parameters of male Guinea pigs," Asian Pacific Journal of Tropical Medicine, vol. 3, no. 3, pp. 200-204, 2010.

[38] D. C. Don Lawson, "Proximate analysis and phytochemical screening of Irvingia gabonensis (Ogbono cotyledon)," Biomedical Journal of Scientific \& Technical Research, vol. 5, no. 4, pp. 4643-4646, 2018.

[39] O. O. Ekpe, C. O. Nwaehujor, C. E. Ejiofor, W. Arikpo Peace, E. Woruji Eliezer, and T. Amor Emmanuel, "Irvingia gabonensis seeds extract fractionation, its antioxidant analyses and effects on red blood cell membrane stability," PhOL, vol. 1, pp. 337-353, 2019.

[40] G. E. Trease and W. C. Evans, A Textbook of Pharmacognosy, Bailliere Tindall Ltd, London, UK, 1989.

[41] A. Sofowora, Medicinal Plants and Traditional Medicine in Africa, Spectrum Books Ltd, Ibadan, Nigeria, 1993.

[42] O. E. Olorundare, A. A. Adeneye, A. O. Akinsola, D. A. Sanni, M. Koketsu, and H. Mukhtar, "Clerodendrum volubile ethanol leaf extract: a potential antidote to doxorubicin-induced cardiotoxicity in rats," Journal of Toxicology, vol. 2020, Article ID 8859716, 17 pages, 2020.

[43] National Research Council (US) Committee for the Update of the Guide for the Care and Use of Laboratory Animals, Guide for the Care and Use of Laboratory Animals, The National Academies Press, Washington, DC, USA, 2011.

[44] R. D. Abbott, P. W. Wilson, W. B. Kannel, and W. P. Castelli, "High density lipoprotein-cholesterol, total cholesterol screening and myocardial infarction: the Framingham study," Arteriosclerosis, vol. 8, no. 3, pp. 207-211, 1988.

[45] S. Alladi and K. R. Shanmugasundaram, "Induction of hypercholesterolemia by supplementing soy protein with acetate generating amino acids," Nutrition Reports International, vol. 40, pp. 893-899, 1989.

[46] J. Zheng, H. C. M. Lee, M. M. bin Sattar, Y. Huang, and J. S. Bian, "Cardioprotective effects of epigallocatechin-3-gallate against doxorubicin-induced cardiomyocyte injury," European Journal of Pharmacology, vol. 652, no. 1-3, pp. 82-88, 2011.

[47] S. Polena, M. Shikara, S. Naik et al., "Troponin I as a marker of doxorubicin induced cardiotoxicity," Proceedings of the Western Pharmacology Society, vol. 48, pp. 142-144, 2005.

[48] A. Shahzadi, I. Sonmez, O. Allahverdiyev et al., "Cardiac troponin-I (cTnI) a biomarker of cardiac injuries induced by doxorubicin alone and in combination with ciprofloxacin, following acute and chronic dose protocol in Sprague Dawley rats," International Journal of Pharmacology, vol. 10, no. 5, pp. 258-266, 2014.

[49] R. Simões, L. M. Silva, A. L. V. M. Cruz, V. G. Fraga, A. de Paula Sabino, and K. B. Gomes, "Troponin as a cardiotoxicity 
marker in breast cancer patients receiving anthracycline-based chemotherapy: a narrative review," Biomedicine \& Pharmacotherapy, vol. 107, pp. 989-996, 2018.

[50] R. Zilinyi, A. Czompa, A. Czegledi et al., "The cardioprotective effect of metformin in doxorubicin-induced cardiotoxicity: the role of autophagy," Molecules, vol. 23, no. 5, article 1184, 2018.

[51] M. F. Alam, G. Khan, M. M. Safhi et al., "Thymoquinone ameliorates doxorubicin-induced cardiotoxicity in Swiss albino mice by modulating oxidative damage and cellular inflammation," Cardiology Research and Practice, vol. 2018, Article ID 1483041, 6 pages, 2018.

[52] M. Adamcova, V. Skarkova, J. Seifertova, and E. Rudolf, "Cardiac troponins are among targets of doxorubicininduced cardiotoxicity in hiPCS-CMs," International Journal of Molecular Sciences, vol. 20, no. 11, article 2638, 2019.

[53] E. K. C. Kong, S. Yu, J. E. Sanderson, K. B. Chen, Y. Huang, and C. M. Yu, "A novel anti-fibrotic agent, baicalein for the treatment of myocardial fibrosis in spontaneously hypertensive rats," European Journal of Pharmacology, vol. 658, no. 23, pp. 175-181, 2011.

[54] B. A. Freeman and J. D. Crapo, "Biology of disease free radicals and tissue injury," Laboratory Investigation, vol. 47, no. 5, pp. 412-426, 1982.

[55] S. Gaweł, M. Wardas, E. Niedwork, and P. Wardas, "Malondialdehyde (MDA) as a lipid peroxidation marker," Wiadomosci Lekarskie, vol. 57, no. 9-10, pp. 453-455, 2004.

[56] S. H. Kim, K. M. Lim, J. Y. Noh et al., "Doxorubicin-induced platelet procoagulant activities: an important clue for chemotherapy-associated thrombosis," Toxicological Sciences, vol. 124, no. 1, pp. 215-224, 2011.

[57] I. Ben Aharon, H. Bar Joseph, M. Tzabari et al., "Doxorubicininduced vascular toxicity - targeting potential pathways may reduce procoagulant activity," PLoS One, vol. 8, no. 9, article e75157, 2013.

[58] H. Lv, R. Tan, J. Liao et al., "Doxorubicin contributes to thrombus formation and vascular injury by interfering with platelet function," American Journal of Physiology-Heart and Circulatory Physiology, vol. 319, no. 1, pp. H133-H143, 2020.

[59] G. F. Samelis, G. P. Stathopoulos, D. Kotsarelis, I. Dontas, C. Frangia, and P. E. Karayannacos, "Doxorubicin cardiotoxicity and serum lipid increase is prevented by dextrazoxane (ICRF-187)," Anticancer Research, vol. 18, no. 5A, pp. 33053309, 1998.

[60] Y. M. Hong, H. S. Kim, and H.-R. Yoon, "Serum lipid and fatty acid profiles in adriamycin-treated rats after administration of L-carnitine," Pediatric Research, vol. 51, no. 2, pp. 249-255, 2002.

[61] J. Lee, M. Chung, Z. Fu, J. Choi, and H. J. Lee, “The effects of Irvingia gabonensis seed extract supplementation on anthropometric and cardiovascular outcomes: a systematic review and meta-analysis," Journal of the American College of Nutrition, vol. 39, no. 5, pp. 388-396, 2020.

[62] S. E. Kuyooro, E. O. Abam, and E. B. Agbede, "Hypolipidemic effects of Irvingia gabonensis - supplemented diets in male Albino rats," Biochemistry \& Analytical Biochemistry, vol. 6, no. 2, article 1000316, 2017.

[63] J. O. Fatoki, O. T. Adedosu, O. K. Afolabi et al., "Dyslipidemic effect of doxorubicin and etoposide: a predisposing factor for the antineoplastic drugs-induced cardiovascular diseases,"
Research \& Reviews: Journal of Pharmacology and Toxicological Studies, vol. 6, no. 1, pp. 34-42, 2018.

[64] I. Mentoor, T. Nell, Z. Emjedi, P. J. van Jaarsveld, L. de Jager, and A. M. Engelbrecht, "Decreased efficacy of doxorubicin corresponds with modifications in lipid metabolism markers and fatty acid profiles in breast tumors from obese vs. lean mice," Frontiers in Oncology, vol. 10, p. 306, 2020.

[65] S. Arunachalam, P. B. Tirupathi Pichiah, and S. Achiraman, "Doxorubicin treatment inhibits PPAR $\gamma$ and may induce lipotoxicity by mimicking a type 2 diabetes-like condition in rodent models," FEBS Letters, vol. 587, no. 2, pp. 105-110, 2013.

[66] J. L. Ngondi, J. E. Oben, and S. R. Minka, "The effect of Irvingia gabonensis seeds on body weight and blood lipids of obese subjects in Cameroon," Lipids in Health and Disease, vol. 4, no. 1, p. 12, 2005.

[67] J. E. Oben, J. L. Ngondi, and K. Blum, "Inhibition of Irvingia gabonensis seed extract (OB131) on adipogenesis as mediated via down regulation of the PPARgamma and leptin genes and up-regulation of the adiponectin gene," Lipids in Health and Disease, vol. 7, no. 1, p. 44, 2008.

[68] J. L. Ngondi, B. C. Etoundi, C. B. Nyangono, C. M. F. Mbofung, and J. E. Oben, "IGOB131, a novel seed extract of the West African plant Irvingia gabonensis, significantly reduces body weight and improves metabolic parameters in overweight humans in a randomized double-blind placebo controlled investigation," Lipids in Health and Disease, vol. 8, no. 1, p. 7, 2009.

[69] I. Onakpoya, L. Davies, P. Posadzki, and E. Ernst, “The efficacy of Irvingia gabonensis supplementation in the management of overweight and obesity: a systematic review of randomized controlled trials," Journal of Dietary Supplements, vol. 10, no. 1, pp. 29-38, 2013.

[70] M. Lee, D. E. Nam, O. K. Kim, T. J. Shim, J. H. Kim, and J. Lee, "Anti-obesity effects of African mango (Irvingia gabonesis, IGOB 131TM) extract in leptin-deficient obese mice," Journal of the Korean Society of Food Science and Nutrition, vol. 43, no. 10, pp. 1477-1483, 2014.

[71] B. Azantsa, D. Kuate, R. Chakokam, G. Paka, B. Bartholomew, and R. Nash, "The effect of extracts of Irvingia gabonensis (IGOB131) and Dichrostachys glomerata (Dyglomera ${ }^{\mathrm{TM}}$ ) on body weight and lipid parameters of healthy overweight participants," Functional Foods in Health and Disease, vol. 5, no. 6, pp. 200-208, 2015.

[72] S. Patra, S. Nithya, B. Srinithya, and S. M. Meenakshi, "Review of medicinal plants for anti-obesity activity," Translational Biomedicine, vol. 6, no. 3, 2015.

[73] Y. Yoshida and E. Niki, "Antioxidant effects of phytosterol and its components," Journal of Nutritional Science and Vitaminology, vol. 49, no. 4, pp. 277-280, 2003.

[74] S. Meguro, K. Higashi, T. Hase et al., "Solubilization of phytosterols in diacylglycerol versus triacylglycerol improves the serum cholesterol-lowering effect," European Journal of Clinical Nutrition, vol. 55, no. 7, pp. 513-517, 2001.

[75] I. Demonty, R. T. Ras, H. C. M. van der Knaap et al., "Continuous dose-response relationship of the LDL-cholesterollowering effect of phytosterol intake," The Journal of Nutrition, vol. 139, no. 2, pp. 271-284, 2009.

[76] R. T. Ras, J. M. Geleijnse, and E. A. Trautwein, "LDL-cholesterol-lowering effect of plant sterols and stanols across different dose ranges: a meta-analysis of randomised controlled studies," The British Journal of Nutrition, vol. 112, no. 2, pp. 214-219, 2014. 
[77] E. Trautwein, M. Vermeer, H. Hiemstra, and R. Ras, "LDLcholesterol lowering of plant sterols and stanols - which factors influence their efficacy?" Nutrients, vol. 10, no. 9, article 1262, 2018.

[78] C. Yuan, X. Zhang, X. Long, J. Jin, and R. Jin, "Effect of $\beta$-sitosterol self-microemulsion and $\beta$-sitosterol ester with linoleic acid on lipid-lowering in hyperlipidemic mice," Lipids in Health and Disease, vol. 18, no. 1, p. 157, 2019.

[79] S. Abu-Lafi, M. Rayan, M. Masalha et al., "Phytochemical composition and biological activities of wild Scolymus maculatus L.," Medicine, vol. 6, no. 2, p. 53, 2019.

[80] M. Saleem, I. Murtaza, R. S. Tarapore et al., "Lupeol inhibits proliferation of human prostate cancer cells by targeting beta-catenin signaling," Carcinogenesis, vol. 30, no. 5, pp. 808-817, 2009.

[81] L. S. Wei, W. Wee, J. Y. F. Siong, and D. F. Syamsumir, "Characterization of anticancer, antimicrobial, antioxidant properties and chemical compositions of Peperomia pellucida leaf extract," Acta Medica Iranica, vol. 49, no. 10, pp. 670-674, 2011.

[82] Y. Song and S. K. Cho, "Phytol induces apoptosis and ROS mediated protective autophagy in human gastric adenocarcinoma AGS cells," Biochemistry and Analytical Biochemistry, vol. 4, p. 211, 2015.

[83] R. Amarowicz, "Squalene: a natural antioxidant?," European Journal of Lipid Science and Technology, vol. 111, no. 5, pp. 411-412, 2009.

[84] S.-K. Kim and F. Karadeniz, "Biological importance and applications of squalene and squalane," Advances in Food and Nutrition Research, vol. 65, pp. 223-233, 2012.

[85] A. Ben Arfa, S. Combes, L. Preziosi-Belloy, N. Gontard, and P. Chalier, "Antimicrobial activity of carvacrol related to its chemical structure," Letters in Applied Microbiology, vol. 43, no. 2, pp. 149-154, 2006.

[86] E. N. Muzalevskaya, L. A. Miroshnichenko, V. A. Nikolaevskii et al., "Squalene: physiological and pharmacological properties," Eksperimental'naia $i$ Klinicheskaia Farmakologiia, vol. 78, no. 6, pp. 30-36, 2015.

[87] B. Venkata Raman, L. A. Samuel, M. P. Saradhi et al., “Antibacterial, antioxidant activity and GC-MS analysis of Eupatorium odoratum," Asian Journal of Pharmaceutical and Clinical Research, vol. 5, no. 2, pp. 99-106, 2012.

[88] M. K. Swamy, G. Arumugam, R. Kaur, A. Ghasemzadeh, M. M. Yusoff, and U. R. Sinniah, "GC-MS based metabolite profiling, antioxidant and antimicrobial properties of different solvent extracts of MalaysianPlectranthus amboinicusLeaves," Evidence-Based Complementary and Alternative Medicine, vol. 2017, Article ID 1517683, 10 pages, 2017.

[89] W. Cordier and V. Steenkamp, "Herbal remedies affecting coagulation: a review," Pharmaceutical Biology, vol. 50, no. 4, pp. 443-452, 2012.

[90] S. Mahmud, S. Akhter, M. A. Rahman et al., "Antithrombotic effects of five organic extracts of Bangladeshi plants in vitro and mechanisms in in silico models," eCAM, vol. 2015, article 782742, pp. 1-8, 2015.

[91] V. T. Thom, N. H. Tung, D. van Diep et al., “Antithrombotic activity and saponin composition of the roots of Panax bipinnatifidus Seem. growing in Vietnam," Pharmacognosy Research, vol. 10, no. 4, pp. 333-338, 2018.
[92] D. Gogoi, A. Pal, P. Chattopadhyay, S. Paul, R. C. Deka, and A. K. Mukherjee, "First report of plant-derived $\beta$-sitosterol with antithrombotic, in vivo anticoagulant, and thrombuspreventing activities in a mouse model," Journal of Natural Products, vol. 81, no. 11, pp. 2521-2530, 2018.

[93] P. S. Salunkhe, S. D. Patil, and S. R. Dhande, “Anti-thrombotic activity of isolated $\beta$-sitosterol from roots of Hemidesmus indicus Linn. in rat model," Journal of Pharmacognosy and Phytochemistry, vol. 7, no. SP6, pp. 10-14, 2018. 